\author{
디지털 음향측심기를 이용한 광양만 잘피(Zostera marina L.)의 \\ 피도와 생물량 추정 \\ 김근용 · 김주형 · 김광용* \\ (전남대학교 해양학과)
}

\title{
Using a Digital Echosounder to Estimate Eelgrass (Zostera marina L.) Cover and Biomass in Kwangyang Bay
}

\author{
Keunyong Kim, Ju-hyoung Kim and Kwang Young Kim* \\ Department of Oceanography, Chonnam National University, Gwangju 500-757, Korea
}

\begin{abstract}
Eelgrass beds are very productive and provide nursery functions for a variety of fish and shellfish species. Management for the conservation of eelgrass beds along the Korean coasts is critical, and requires comprehensive strategies such as vegetation mapping. We suggest a mapping method to spatial distribution and quantify of eelgrass beds using a digital echosounder. Echosounding data were collected from the northeast part of Kwangyang Bay, on the south of Korea, in March, 2007. A transducer was attached to a boat equipped with a DGPS. The boat completed a transect survey scanning whole eelgrass beds of $11.7 \mathrm{~km}^{2}$ with a speed of 1.5-2 $\mathrm{m} \mathrm{s}^{-1}$ (3-4 knot). The acoustic reflectivity of eelgrass allowed for detection and explicit measurements of canopy cover and height. The results showed that eelgrass bed was distributed in depth from 1.19 to $3.6 \mathrm{~m}$ (below MSL) and total dry weight biomass of 4.1 ton with a vegetation area of $4.05 \mathrm{~km}^{2}$. This technique was found to be an effective way to undertake the patch size and biomass of eelgrass over large areas as nondestructive sampling.
\end{abstract}

Key Words: acoustic reflectivity, biomass, canopy cover, digital echosounder, eelgrass beds, Kwangyang Bay, vegetation mapping

서 론

잘피(Zostera marina L.)는 극지방을 제외한 전 세계 연안, 염습지, 하구 등에서 생육하는 관속 현화식물이다(Fortes 1986). 잘피는 광합성 생산력이 높고 유기 쇄설물을 생산하 고 포획하며 용존 유기물을 분비하여 주변 생태계의 영양염 순환을 주도한다(Duarte and Cebrián 1996). 또한 경제적 가 치가 큰 어류의 서식, 피난 및 성육장을 제공하고(Thayer et al. 1984; Short and Neckles 1999) 연안환경의 오염수준을 지 시하는 지표종으로 이용되기(Pergent-Martini et al. 2006)때 문에 잘피의 생육 분포와 생물량 파악은 연안환경의 보전과 지속 가능한 생태계 이용을 위해 필요한 연구이다.

잘피의 성장에 필요한 최소한의 빛은 표층 광량의 $4 \%$ 에서

*Corresponding author (kykim@chonnam.ac.kr)
$29 \%$ 정도이고 평균 $11 \%$ 이다(Duarte 1991; Dennison et al. 1993). 이는 해조류나 식물플랑크톤의 생장에 필요한 최소 광량보다 더 높은 값을 필요로 한다는 것이다(Duarte 1995). 잘피의 분포는 해수의 탁도, 퇴적물의 특성 등에 따라 그 범 위가 제한되는데(Livingston et al. 1998) 한국 남해안에서 잘 피는 대부분 파도의 영향으로부터 보호되는 사질이나 니질 의 만에 흔히 분포한다(이 등 2001; Kim and Choi 2004). 광 양만 개발 이전인 1970 년대에는 주변의 많은 섬들과 육지 사 이의 앝은 바다에 왕성한 잘피군락이 넓게 분포하고 있었으 나 1980년대 이후 광양제철소 건설과 같은 대규모의 광양만 개발사업과 가동 중에 준설작업 등으로 상당 규모의 잘피군 락이 유실되었을 것으로 추정하고 있다. 최근 인근 해역의 화력발전소 건설과 가동으로 탁도가 증가하고 해수의 흐름 이 바뀌는 등의 환경변화가 가중되어 현재와 같은 소규모 군 락이 간간히 유지되고 있을 뿐이다(Kim and Choi 2004).

수중식생(submersed aquatic vegetation, SAV)의 분포 및 
생물량 조사 방법으로 다이빙 등을 통한 직접적인 채집 방법 에서 수중카메라, 인공위성 및 항공사진 이용, 수중음향 탐 사방법까지 다양한 시도가 이루어진 바 있다(Dennis 1984; Madsen 1993). 예로부터 흔히 이용되고 있는 다이빙을 통한 직접 채집 방법은 좁은 지역을 정밀하게 조사하는 연구에는 적합하지만 많은 노동력과 시간을 필요로 하기 때문에 조사 의 대상지역 규모가 극히 제한될 수 밖에 없다(Sabol et al. 2002). 인공위성, 항공사진 등을 이용하여 식생을 분석하는 방법은 적은 노동으로 광범위한 조사지역을 파악할 수 있는 장점은 있지만 전체적인 경관(landscape) 분포를 파악하는데 만족해야 하고 해양에서 수심이나 탁도 등에 따라 식생의 해 상도가 달리 나타나기 때문에 정밀한 자료를 얻을 수 없다 (Mumford et al 1995). 수중카메라를 이용한 방법은 직접 다 이빙하여 촬영하거나 약 $1 \mathrm{~m} \mathrm{~s}^{-1}$ 로 선박을 운행하면서 녹화 한 수중 영상 자료로부터 식생의 분포 및 생물량을 추정한 다. 이 방법 역시 식생의 종 동정과 밀도 파악은 가능하겠지 만 수심이나 해수의 탁도에 영향을 받고 탐지 가능한 면적이 제한되는 단점이 있다(Norris et al. 1997).

본 연구에서 채택한 수중음향을 이용한 수중식생 분석은 식생의 밀도와 더불어 식물의 길이 정보를 얻을 수 있다 (Sabol et al. 2002; 강 등 2006; Winfield et al. 2007). 디지털 음향측심기는 수중에 음파를 쏘아 바닥에 반사되는 값을 이 용하여 수심을 결정하는데, 만약 저서 식물군집이나 식물의 줄기 또는 잎에 음파가 닿게 되면 바닥에 음파가 닿기 전에 반사되어 수신된다. 이러한 원리를 이용하여 해저면과 식물 크기를 측정할 수 있다. 또한 GPS(global positioning system)를 이용하여 실시간으로 위치 정보와 함께 음향정보 를 저장하기 때문에 적은 노동과 시간으로 광범위한 조사가 가능하다(Sabol et al. 2002; 강 등 2006).

수중음향을 이용한 수중식생 분석 연구는 주로 수생식물 의 생물량 및 저질 특성을 파악하기 위해 개발되었다(Stent and Hanley 1985; Carbo and Molero 1997; Guan et al. 1999; Sabol et al. 2002). 디지털 음향측심기로 측정된 자료에 서 수중식생(SAV)을 분리해낼 수 있는 소프트웨어가 최근 개발되었고, 수중음향을 이용한 연구가 어류, 부유생물, 해양 지질 분야에서 활발히 이루어지고 있다(Sabol et al. 2002;

Komatsu et al. 2003; Erhan 2005; Haga et al. 2007; Kevin et al. 2007).

국내에서 잘피를 비롯한 수중식생에 대한 연구는 주로 다 이빙을 통한 직접 샘플링 방법에 의존하였으나 최근 강 등 (2006)은 수중음향을 이용하여 경상남도 남해군의 북쪽에 위 치한 창선도 동대만 잘피의 공간 및 수직적 분포를 조사한 바 있다. 그러나 이들은 잘피의 생물량을 추정하는 과정에서 잘피군락의 팻치(patch) 및 가장자리(edge) 효과 특성을 충분 히 고려하지 못하였다. 광양만의 잘피 군락은 낮은 밀도와

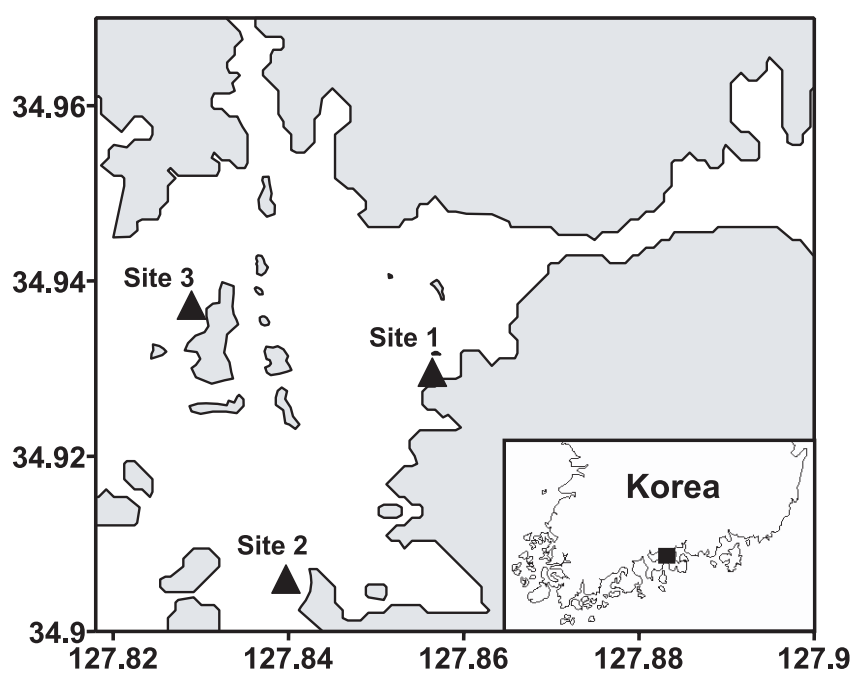

Fig. 1. Map showing the study area and three eelgrass vegetations.

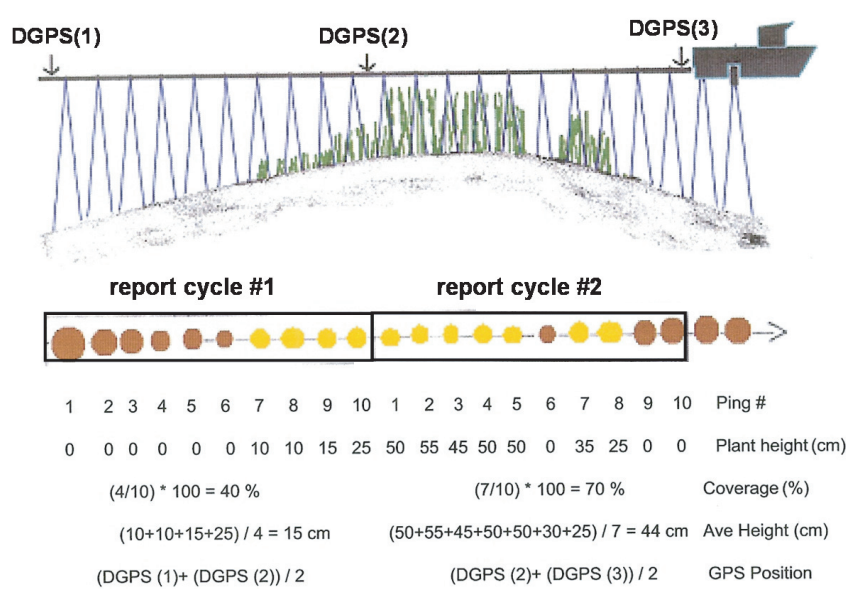

Fig. 2. Processing and reporting for survey in hypothetical vegetated area. Circles indicate bottom area of ping, brown circle for bare and yellow for bare (Sabol et al. 2002).

생물량 그리고 다양한 크기의 팻치가 단절(fragmentation)되 어 나타난다(Kim and Choi 2004), 이와 같이 특이한 잘피식 생의 경우, 다이빙이나 그랩 같은 직접 채집 방법 보다는 간 접적이지만 넓은 범위에서 자세한 정보를 획득할 수 있는 디 지털 음향측심기를 이용한 방법이 더 유용할 것으로 기대된 다. 또한 연안 생태계 보전과 효율적 이용을 위해서 수중식 생에 대한 지역 수준의 중규모 분포 정보가 필요하고, 조사 방법에 있어서 비파괴적이고 지속적인 모니터가 가능해야 할 것이다. 본 연구는 수중식생의 직접 샘플링에 의한 연안 해양생물의 훼손을 줄이고 광범위하게 분포하는 잘피식생을 효율적으로 조사하고 관리할 수 있는 디지털 수중음향측심 기술의 이용과 응용 가치를 평가하기 위해 수행되었다. 


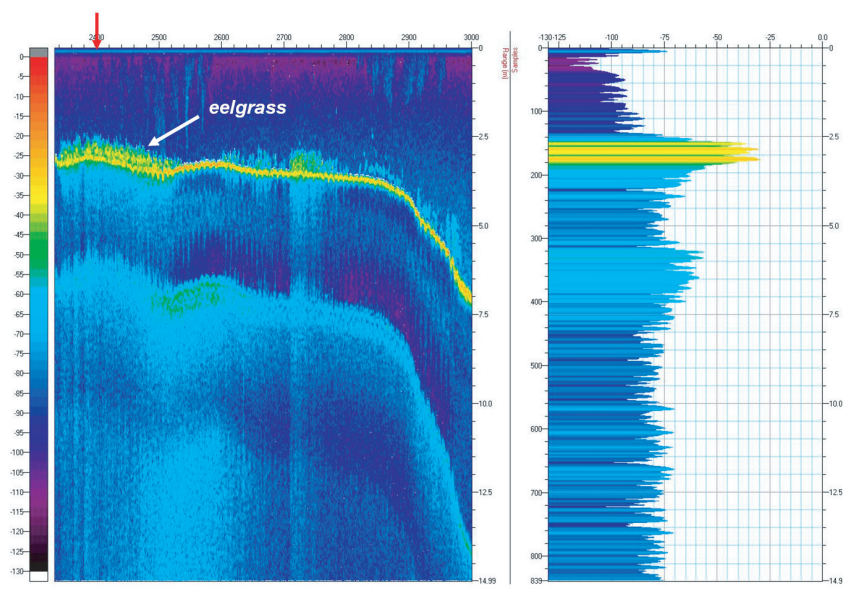

Fig. 3. Example of echogram obtained from Biosonics echosounder in an eelgrass bed. Pictures show bottom along track, ping by ping (left) and oscilloscope display showing voltage return for ping \# 2400 only (right). Eelgrass shoots are green on soft bottom (yellow).

\section{재료 및 방법}

광양만은 전라남도 여수시 낙포각과 광양시 하포의 장길 곶 사이에 위치해 있으며 만 입구는 동쪽으로 열려 있다. 만 입구의 폭은 $9 \mathrm{~km}$, 전체 길이는 $17 \mathrm{~km}$ 정도로 수심은 보통 20-30 m이다. 문헌과 현지 탐문을 통해 잘피(Zostera marina L.) 생육이 확인된 동북부 광양만에서 2007년 3월 25-26일에 현장조사가 이루어졌다. 조사는 광양만 내부에 있는 소항도 와 남해군 덕신리 사이(정점 1 ), 남해군 갈화마을 해안(정점 2), 화동화력발전소와 마주 보는 대도섬 서쪽(정점 3) 3곳에 서 이루어 졌고 모든 정점에서 잘피 단일종 식생이 확인되었 다(Fig. 1).

섬과 육지 사이에 수로가 있어 이 구역을 제외한 정점 1 의 잘피군락은 유속이 다른 정점에 비해 낮고 주로 니질의 퇴적 물로 되어있다. 정점 2의 경우 반 폐쇄성의 지형으로 둘러 쌓 여 있으나 정점 1 에 비해 유속이 약간 크고 퇴적물은 주로 니질로 되어 있다. 정점 3은 하동화력발전소와 광양만 내부 대도 사이에 위치하여 다른 두 정점에 비해 유속이 크고, 퇴 적물의 사질 함량이 더 높다(Kim and Choi 2004).

연구에 사용된 음향측심기는 DT-X Digital Echosounder (Biosonics Inc. USA)이고 $420 \mathrm{kHz}$ 의 단일빔(Single-beam) 센서로 빔 폭은 $6^{\circ}$ 이며 미세 신호까지 수신이 가능하다. 잘피 의 음향신호를 수신하기 위하여 송신 신호의 폭(pulse width)은 $0.1 \mathrm{~ms}$, 센서의 송신 간격(pings rate)은 5 pings s${ }^{-1}$ 로 설정하였다. 음향송수신기(transducer)는 저항을 최소화 할 수 있는 예인선(Biofin dead weight towing vehicle; Biosonics, USA)에 고정시킨 후 조사 선박에 장착하였다. 조 사하는 동안 발생할 수 있는 방해 요인들을 최소화 하기 위
해 음향 송수신기를 수면으로부터 $0.5 \mathrm{~m}$ 잠긴 위치에 장착하 였고, 선박 이동으로 인하여 발생할 수 있는 기포의 영향을 최소화 하기 위해 속도는 1.5-2 m s $\mathrm{m}^{-1}$ (3-4 knot)로 유지하였 다. 위도와 경도 정보는 상대적으로 거리 오차가 적은 DGPS (Differential Global Positioning System)로부터 얻었고 이는 음향자료와 동시에 저장되어 $\mathrm{SAV}$ 의 지리적 분포를 파악하 는데 이용되었다. 해안선을 기준으로 하여 해안선과 평행하 게 이동하면서 조사가 이루어졌으며 조위에 따른 수심 및 잘 피의 서식 깊이를 결정하기 위하여 평균해수면(Mean Sea Level, MSL)를 기준으로 수심을 보정했다. 음향자료는 EcoSAV 1.0 (Biosonics, USA) 소프트웨어를 통해 잘피의 존 재유무, 수관의 높이(canopy height), 수심 데이터로 변환되 었다. 이 자료는 각 사이클(cycle)의 피도, 평균 크기, 위치정 보를 산출하는데, 하나의 사이클은 15 개의 pings로 구성된다 (Figs 2, 3).

디지털 음향측심기로 측정된 잘피의 피도는 생물량 $(\mathrm{g} \mathrm{DW}$ $\mathrm{m}^{-2}$ )으로 환산하였는데, 이를 위해 7개 지점에서 음향측심기 의 피도와 직접 취하여 구한 생물량 간의 회귀식을 이용하였 다. 정점 2에서 음향측심기가 지나간 정선을 따라 부표를 낙 하시켜 표지한 후, SCUBA를 통해 표지된 지점의 앞과 뒤로 각 $3 \mathrm{~m}$ 거리에서 $25 \times 25 \mathrm{~cm}$ 방형구를 이용하여 $2 \mathrm{~m}$ 간격으 로 3 개의 샘플을 채취하였다. 각 지점에서 $6 \mathrm{~m}$ 거리는 $\mathrm{EcoSAV}$ 소프트웨어가 분석하는 한 싸이클의 거리에 해당한 다. 즉, 한 싸이클은 15 개 pings의 평균값인데, 1 초에 5 번의 ping이 발사되고 조사 선박은 $2 \mathrm{~m} \mathrm{~s}^{-1}$ 로 이동하면 싸이클 당 탐지 거리는 약 $6 \mathrm{~m}$ 가 된다. 방형구 내에서 수집한 잘피는 실험실로 옮겨와 개체수와 엽조의 길이를 측정한 후 $60^{\circ} \mathrm{C}$ 에 서 72 시간 동안 건조하여 건조량 $\left(\mathrm{g} \mathrm{DW} \mathrm{m}^{-2}\right)$ 을 구하였다.

결

과

광양만 북동해역 3 개 정점에서 디지털 음향측심기를 이용 하여 조사한 총 면적은 $11.7 \mathrm{~km}^{2}$ 이었다. 음향조사 결과, 조 사 지점 간에 잘피의 생육 수심 및 엽조의 크기가 다르게 나 타났다. 소항도와 덕신리 연안 사이에 위치한 정점 1에서는 잘피가 평균해수면(MSL) 이하 1.19-2.42 m 범위에서 출현하 였고, $60 \%$ 이상의 피도를 보이는 수심은 약 $1.9 \mathrm{~m}$ 이었다 (Fig. 4A), 갈화마을 연안에 위치한 정점 2에서는 잘피가 평 균해수면 이하 1.9-3 m의 수심에 분포하였으며, 약 $2.5 \mathrm{~m}$ 수 심에서 상대적으로 높은 피도를 나타내었다(Fig. 4B). 하동화 력발전소 인근 대도섬 서쪽의 정점 3에서는 수심 2.6-3.6 m 범위에서 잘피가 생육하였고 분포의 중심은 대략 $3.2 \mathrm{~m}$ 수심 이었다(Fig. 4 C). 잘피의 분포 면적은 정점 1 에서 약 3.04 $\mathrm{km}^{2}$, 정점 2 에서 $0.91 \mathrm{~km}^{2}$, 정점 3 에서는 $0.09 \mathrm{~km}^{2}$ 로 계산되 었다. 


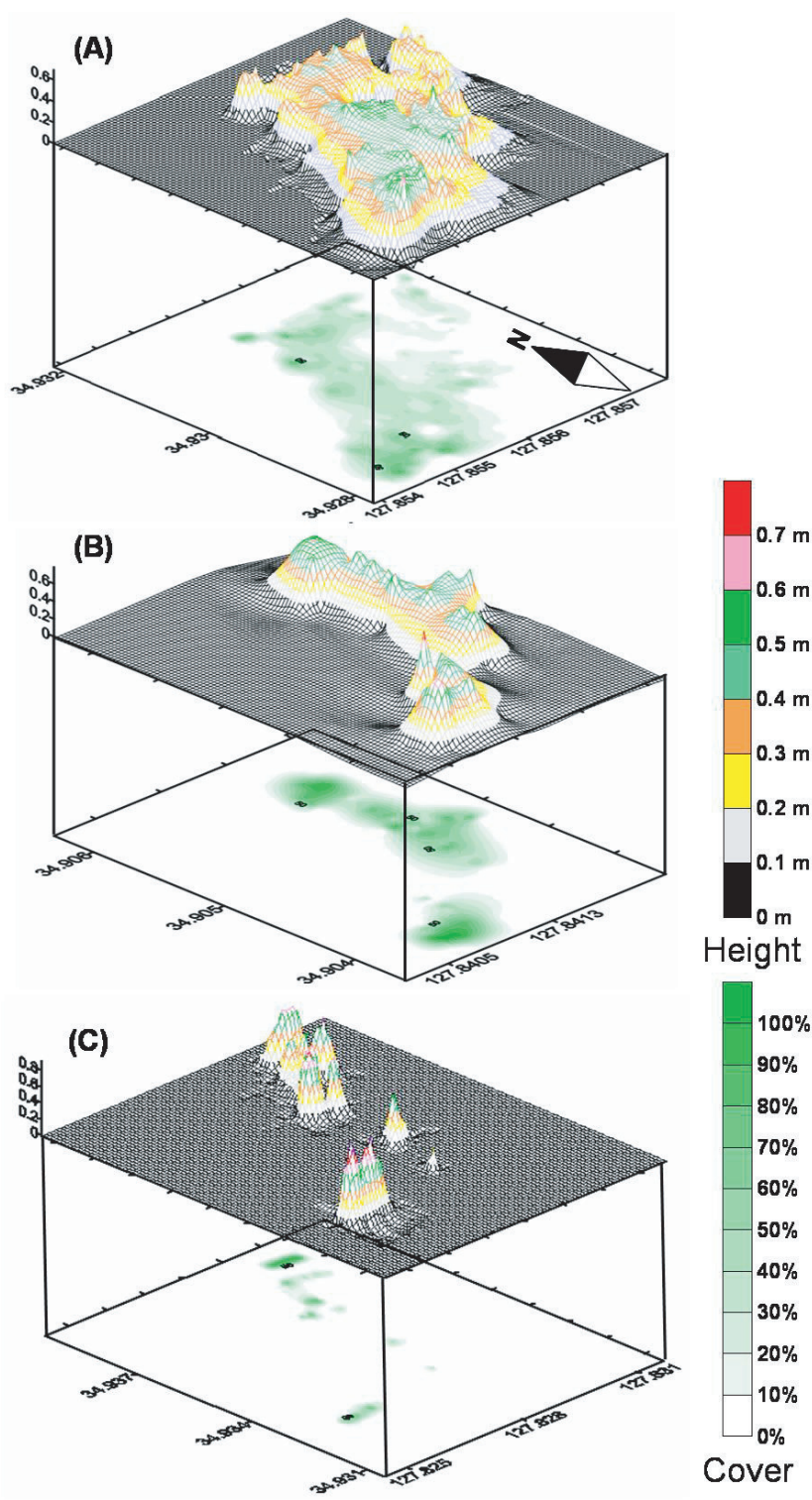

Fig. 4. Combined presentation of cover (below, in percent) and height (above, in meters) of eelgrass. Site 1 (A), Site 2(B) and Site 3(C).

정점 1 의 잘피 식생은 두 개의 팻치로 나누어 지는데 식생 중심에서 북동쪽에 위치한 조그마한 섬(소항도)과 육지(남해 군 덕신리) 사이를 흐르는 강한 해류와 선박의 통행이 빈번 한 행로를 기점으로 분리되었다. 두 팻치 간의 면적 차이는 대략 7배에 이르렀다(Fig. 4A). 정점 2에서는 더욱 뚜렷한 두 개의 팻치로 구분되는데, 북동쪽의 팻치가 남서쪽 보다 약 3 배 가량 넓은 면적을 보였다(Fig. 4B). 한편 정점 3에서는 다 른 정점의 팻치 크기에 비해 상대적으로 작은 두 개의 팻치 가 북동쪽과 남서쪽 방향으로 줄지어 있고 그 사이에 아주 작은 규모의 잘피 팻치가 자리잡고 있었다(Fig. 4C).

EcoSAV 소프트웨어는 음향측심자료를 잘피의 피도와 엽 조 크기 자료로 분석할 수 있었다. 정점 1 에서 생육하는 잘
피의 피도 및 크기 분포양상을 살펴보면, 대부분의 면적에서 $60 \%$ 미만의 피도로 나타났고 $80-100 \%$ 피도계급은 3\%이었 다. 피도 계급 20-40\%는 정점 1에서 나타난 잘피 면적의 $37 \%$ 를 차지하였고 $40-60 \%$ 피도계급은 잘피 면적의 $23 \%$, 60-80\% 피도계급은 $6.4 \%$ 를 차지하였다(Fig. $5 \mathrm{~A})$. 이곳에서 잘피의 크기는 $0.2-0.5 \mathrm{~m}$ 가 대부분이었고 $(89 \%)$, 이들 중에 서 0.2-0.4 m 크기계급이 $32.6 \%$ 로 가장 많았으나 $0.6-0.7 \mathrm{~m}$ 크기계급은 $1.6 \%$ 에 불과하였다(Fig. $5 \mathrm{~B}$ ). 정점 2 에서 잘피는 대부분의 면적에서 $40 \%$ 이상의 피도로 나타났고 $20 \%$ 미만 의 피도계급은 6\% 정도로 나타났다. 20-40\% 피도계급은 잘 피 면적의 $8 \%, 40-60 \%$ 피도계급은 $25 \%, 60-80 \%$ 피도계급은 $27 \%$ 를 차지하였으며 $80-100 \%$ 피도계급은 $35 \%$ 로 가장 많은 양을 차지하였다(Fig. 5C). 정점 2에서 잘피의 크기 분포양상 을 살펴보면 $0.3-0.7 \mathrm{~m}$ 크기가 $90 \%$ 를 차지하였고, 그 중 0.4-0.5 크기계급이 $29.3 \%$ 로 가장 많았으며 $0.7-0.8 \mathrm{~m}$ 와 0.9-1.0 m 크기계급은 각각 $1.7 \%$ 에 불과하였다(Fig. 5D). 정 점 3에 생육하는 잘피는 20-40\% 피도계급이 $32.3 \%$ 로 가장 많았고, $20 \%$ 미만의 피도계급은 $12.3 \%$ 를 차지하였다. $40-60 \%$ 피도계급은 $18.5 \%, 60-80 \%$ 피도계급은 $23.1 \%$ 를 차 지하였으며 $80-100 \%$ 피도계급은 $13.8 \%$ 를 차지하여 상대적 으로 고른 피도계급 분포를 보였다(Fig. $5 \mathrm{E})$. 정점 3에서 잘 피 크기 분포의 경우, $0.3-0.8 \mathrm{~m}$ 크기가 $87.1 \%$ 로 대부분이었 고 $1.0-1.1 \mathrm{~m}$ 크기는 $1.4 \%$ 에 그쳤다(Fig. $5 \mathrm{~F})$.

디지털 음향측심기에서 얻은 질피의 피도는 동일 지점에 서 직접 채취하여 구한 생물량과 선형관계를 보였다. 잘피의 피도계급에 따라 음향 세기 $(\mathrm{dB})$ 가 다르게 나타나는데 대상 잘피에서 - $15--65 \mathrm{~dB}$ 의 범위를 보였다. 이와 같은 음향 세기 는 EcoSAV 소프트웨어에서 잘피 피도로 계산된다. 일반적 으로 잘피의 피도는 생물량과 높은 상관이 있기 때문에 음향 측심에 의한 잘피 피도와 생물량 간의 회귀식을 구하여 직접 채취하지 않은 식생의 생물량을 추정하였다. 정점 2 정선에 서 구한 음향측심에 의한 잘피의 피도와 해당 지점에서 직접 구한 잘피 건조 생물량 간의 회귀식은 다음과 같이 표현되었 다.

생물량 $=0.5072 \times$ 음향측심기 피도 $+38.054\left(R^{2}=0.80\right)$

세 정점에서 얻어진 음향자료에 대해 피도계급을 5 개 $(0-20,20-40,40-60,60-80,80-100 \%)$ 로 나누어 각 등급에 해당하는 면적을 계산하였고 위 회귀식을 이용하여 계급 별 로 총 생물량을 구하였다. 정점 1 의 경우, 잘피가 생육하는 총 면적에서 0-20\% 피도계급은 30\%를 차지하였고 생물량 $683.1 \mathrm{~kg} \mathrm{DW}$ 이었다(Table 1). 이곳에서 가장 큰 면적을 차지 하고 있는 20-40\% 피도계급의 생물량은 $1064.8 \mathrm{~kg} \mathrm{DW}$ 이었 다. 이와 같은 방식으로 정점 1 의 모든 피도계급에 대한 생물 

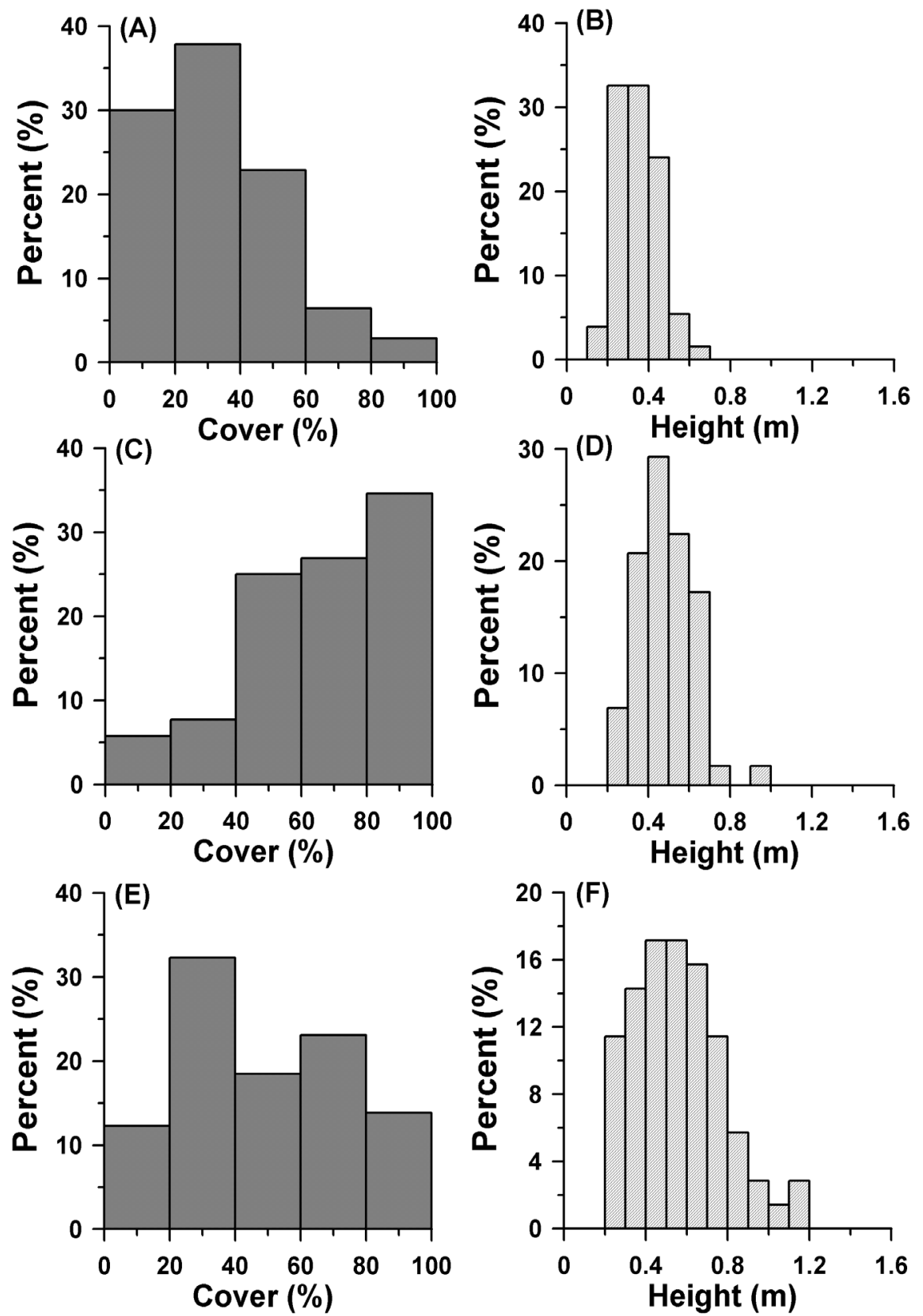

Fig. 5. The distributions of cover (left column) and height (right column) of eelgrass in Site 1(upper), Site 2 (mid) and Site 3 (lower).

량을 계산하여 모두 더하면 정점 1 잘피 식생의 총 생물량으 로 건조량 2.9톤이었다(Table 1). 정점 2의 경우, 잘피 총 면 적에 대한 0-20\% 피도계급의 면적은 $920.8 \mathrm{~m}^{2}$ 이었고 생물량 은 $39.7 \mathrm{~kg}$ DW이었다(Table 1). $80-100 \%$ 피도계급이 차지하 는 면적은 $5524.6 \mathrm{~m}^{2}$ 로 가장 넓은 면적을 차지하였고 생물량 은 $462.4 \mathrm{~kg} \mathrm{DW}$ 이었다. 정점 2에서 출현하는 잘피의 총 생 물량은 건조량으로 1.1 톤이었다. 정점 3 경우, 잘피의 총 면 적에서 20-40\% 피도 계급이 가장 큰 면적을 차지하였고 생 물량은 $28.9 \mathrm{~kg} \mathrm{DW}$ 이었다(Table 1). 0-20\% 피도 계급의 면 적은 $206.8 \mathrm{~m}^{2}$ 로 생물량 $8.9 \mathrm{~kg}$ DW이었다. 정점 3 에서 잘피 군락의 총 생물량은 건조량 0.1 톤이었고 이곳은 조사 정점
중에서 가장 적은 생물량을 보였다.

\section{고 찰}

잘피는 연안에 서식하는 다양한 어류와 무척추동물의 서 식처 및 산란장으로 이용되고 생태 및 산업적으로 중요한 역 할을 가지고 있어 이에 대한 많은 연구가 수행되어 왔다. 특 히 인간 활동의 영향으로 그 생육 범위가 급속히 감소하고 있어 연안 생물 보전 및 자원 관리 차원의 훼손된 잘피 생태 계를 복원해야 할 필요성이 커지고 있다(Pergent-Martini et al. 2006). 잘피 군락을 보전하고 복원하기 위해서는 무엇보 
Table 1. Area and biomass of eelgrass beds in each cover class in three sites of Kwangyang Bay derived from EcoSAV

\begin{tabular}{|c|c|c|c|c|c|c|}
\hline \multirow[b]{2}{*}{ Cover $(\%)$ class } & \multicolumn{2}{|c|}{ Site 1} & \multicolumn{2}{|c|}{ Site 2} & \multicolumn{2}{|c|}{ Site 3} \\
\hline & $\begin{array}{l}\text { Area } \\
\left(\mathrm{m}^{2}\right)\end{array}$ & $\begin{array}{l}\text { Biomass } \\
(\mathrm{DW} \mathrm{kg})\end{array}$ & $\begin{array}{l}\text { Area } \\
\left(\mathrm{m}^{2}\right)\end{array}$ & $\begin{array}{l}\text { Biomass } \\
(\mathrm{DW} \mathrm{kg})\end{array}$ & $\begin{array}{l}\text { Area } \\
\left(\mathrm{m}^{2}\right)\end{array}$ & $\begin{array}{l}\text { Biomass } \\
\text { (DW kg) }\end{array}$ \\
\hline $0-20$ & 15840.0 & 683.1 & 920.8 & 39.7 & 206.8 & 8.9 \\
\hline $20-40$ & 19988.6 & 1064.8 & 1227.7 & 65.4 & 542.8 & 28.9 \\
\hline $40-60$ & 12068.6 & 765.3 & 3990.0 & 253.0 & 310.2 & 19.7 \\
\hline $60-80$ & 3394.3 & 249.7 & 4296.9 & 316.1 & 387.7 & 28.5 \\
\hline $80-100$ & 1508.6 & 126.3 & 5524.6 & 462.4 & 232.6 & 19.5 \\
\hline Sum of biomass (DW ton) & \multicolumn{2}{|c|}{2.9} & \multicolumn{2}{|c|}{1.1} & \multicolumn{2}{|c|}{0.1} \\
\hline
\end{tabular}

다 잘피의 생육 분포 및 생물량 현황을 파악하는 기초 연구 가 선행 되어야 한다. 이와 같은 잘피 식생의 기초 연구를 수 행하기 위해서 다양한 직접 또는 간접적인 방법이 제안되고 있지만 다이빙을 통한 육체적인 방법에 크게 의존하고 있다. 이 방법은 많은 노동과 시간이 필요하기 때문에 단일 연구진 의 노력으로 지역 규모 이상의 자료를 확보하기가 쉽지 않 다. 반면 음향측심을 이용하는 방법은 적은 시간과 노력으로 광범위한 현장 조사가 가능하고 특히 해양 생물을 전혀 훼손 하지 않는 비파괴적인 방법으로 광양만과 같은 지역 규모에 서 반복적인 모니터링 연구에 적합한 것으로 확인되었다.

본 연구에 사용된 디지털 에코사운더(DT-X, Biosonics Inc. USA)는 SAV(submerged aquatic vegetation)의 지리적 분포를 파악하는데 효율적이지만 생물량이 $60 \mathrm{~g} \mathrm{WW} \mathrm{m}^{-2}$ 이 하이거나 식물의 크기가 $8 \mathrm{~cm}$ 이하일 경우에는 정확하게 탐 지되지 않는다(Sabol et al. 2002). 음향측심기를 이용한 수중 식생 탐지 능력은 이외에도 수심, 바람, 파도, 해류 등 다양 한 환경요인에 영향을 받고, 낮은 수심에서는 음향 신호가 노이즈로 나타나기 때문에 식생이 수면에서 최소 $0.5 \mathrm{~m}$ 이상 의 깊이에 존재해야 그 규모를 정확하게 탐지할 수 있다 (Sabol et al. 2002). 또한 식생이 해류나 파도에 의해 흔들리 면 연구 목적에 필요한 정확한 음향값을 얻을 수 없다 (Mohamed 2007), 하지만 북동부 광양만 조사 정점에서 잘피 의 크기는 $0.1 \mathrm{~m}$ 이상이고 생물량은 $153.7 \mathrm{~g} \mathrm{WW} \mathrm{m}^{-2}$ 이었기 때문에 본 연구에 사용된 DT-X 검출한계에 아무런 문제가 없었다. 또한 조차가 적고 조금 때 파고가 낮은 시기를 선택 해 현장 조사하였기 때문에 기기의 음향탐지에 있어서 환경 요인의 영향을 최소화하였다.

북동부 광양만에서 잘피가 생육하는 면적은 $4.05 \mathrm{~km}^{2}$ 이고 총 생물량은 건조량으로 4.1 톤이었다. 조사정점 간의 잘피 피도 및 크기 분포을 비교해 보면, 가장 큰 규모의 잘피 군락 이 형성되어 있는 정점 1 에서 생물량 역시 가장 많았다. 정점 2 에서 잘피 군락은 $60 \%$ 이상의 피도 계급이 대부분 차지하 고 있어 높은 밀도로 생육하고 있었고. 가장 작은 규모의 잘 피 군락을 보인 정점 3 은 작은 규모의 여러 펫치로 구성되었
다. 대체로 낮은 밀도와 생물량 그리고 다양한 크기의 팻치 로 구성된 북동부 광양만의 잘피 식생은 9년 전 $\mathrm{Kim}$ and Choi(2004)에 의해 같은 지점의 봄철 잘피 식생과 비교했을 때 큰 차이를 확인할 수 없었다. 이는 지난 9년 사이에 그 동 안 잘피 식생 변화가 크지 않았다는 것을 의미하지는 않는 다. 2002년 1월부터 12월까지 정 등(2004)에 의해 정점 1 과 3 인근 잘피밭에서 단각류의 계절변동과 식성에 대한 연구가 있었는데, 이 때 잘피의 생물량은 $103-176.4 \mathrm{~g} \mathrm{DW} \mathrm{m}^{-2}$ 이었 다. 이는 본 연구에서 확인한 생물량에 비해 약 2 배에 달한 다. 또한 정점 1 인근에서 이들이 보여준 잘피 생물량은 연 중 $60.0-838.5 \mathrm{~g} \mathrm{DW} \mathrm{m}^{-2}$ 범위로 식생의 단절이 없이 지속해 서 왕성한 식생이 유지되는데 반해 본 조사 이후 실시된 8월 의 식생 분석 결과 정점 1 인근에서 잘피가 거의 사라진 것을 확인하였다. 따라서 북동부 광양만에서 잘피 식생은 계절 및 연간 상당한 폭으로 변화하는 것을 알 수 있는데, 9년 전의 잘피 식생이 이번 연구 결과와 유사한 것은 우연에 불과한 것으로 생각된다.

세 조사 정점 간에 식생의 정량적 차이는 퇴적물 입도 조 성의 차이에서 원인을 찾을 수 있다. 퇴적물 입도 조성은 시 간적으로 큰 변화가 있을 수 있지만 지역 규모의 대체적인 변화는 크지 않을 것이라 가정하고 2000년도 인근 해역의 환 경영향평가 보고서(부경대학교 2000) 자료를 참고하였다. 정 점 1 에서는 sand $1.4 \%$, silt $34.4 \%$ 그리고 clay $64.2 \%$ 로 니질 의 함량이 현저히 높았다. 정점 2에서는 sand $2.4 \%$, silt $84.3 \%$ 그리고 clay $13.3 \%$ 로 역시 니질의 함량이 역시 높았 다. 하지만 정점 3에서는 sand $7.7 \%$, silt $42.4 \%$ 그리고 clay $49.9 \%$ 로 다른 정점보다 사질의 함량이 약 3 배 정도 높은 비 율을 보였다. Kim and Choi (2004)에 따르면 광양만 잘피는 니질의 퇴적물 환경에 잘 적응되어 있어 여기서 생물량이 더 높게 나타난다고 하였다. 본 연구 결과 역시 니질의 함량이 높은 정점에서 잘피 식생이 넓게 분포하였다. 그러나 일반적 으로 잘피는 이와 같은 저질보다 사질의 함량이 높은 퇴적물 에서 선호한다(Lee et al. 2005; Short et al. 2007). 따라서 광양 만의 퇴적물은 잘피 생육에 최적의 환경 여건이 아닐 수 있 
다고 생각할 수 있다. 잘피 생육에 영향을 미치는 요인은 퇴 적물 외에도 광량, 수온, 해류 등이 복합적으로 작용하기 때 문에(Kaldy and Lee 2007) 퇴적물 조성만으로 분포 양상을 정의하는데 어려움이 따른다. 니질 퇴적물 환경은 사질 퇴적 물 환경에 비해 빛 조건에서 불리할 수 있으나 빛이 제한되 지 않는다면 유속이나 영양염 등의 다른 여건에서 유리한 환 경일 수 있기 때문이다.

광양만 잘피 식생은 정점 1 과 2 에서 $2.5 \mathrm{~m}$ 근처의 수심에 서 분포 중심이 있는 반면 정정 3 에서는 $3.2 \mathrm{~m}$ 수심에서 식생 의 분포 중심이었다. 이는 유속과 퇴적물 특성뿐 아니라 저 질의 굴곡과 지형이 잘피의 팻치 모습을 결정하는 것으로 보 인다. 다른 정점에 비해 낮은 피도와 생물량을 나타낸 정점 3 에서 팻치가 여러 개의 크기로 단절되어 나타나는 것은 상대 적으로 수심의 굴곡이 심하고 지형적인 영향으로 유속과 파 도가 다른 정점에 비해 높기 때문인 것으로 생각된다.

음향측심기를 이용하여 일본 산리쿠(Sanriku) 해역에서 $115 \mathrm{~m} \times 156 \mathrm{~m}$ 면적의 잘피 군락을 소형 보트로 40 분만에 조 사하였고(Komatsu et al. 2003), 수중 식생의 피도와 비디오 촬영을 통한 피도 간에 높은 상관관계가 있음을 보인 바 있 다(Winfield et al . 2007). 이와 같이 음향측심기를 이용해서 잘피 식생을 조사할 경우, 선박을 통해 생육 면적의 대부분 을 항적하기(tracking) 때문에 직접 채집 방법으로는 불가능 한 규모의 생물 자료를 얻을 수 있다. 잘피의 선형꽃차례 (rhipidia)는 $100 \mathrm{~km}$ 이상 떨어진 곳까지 군락 형성이 가능하 게 한다(Källström et al. 2008). 이와 같은 규모의 연구는 음 향측심기를 통해 확인 할 수 있을 것이고, 정점 3과 같이 다 양한 크기의 팻치로 쪼개져 있는 군락의 경우, 직접 채집에 비해 생물자료의 오차를 크게 줄일 수 있다. 또한 음향측심 자료를 생물량으로 환산할 경우, 피도계급을 세분하여 자료 의 오차를 줄일 수 있을 것이다.

음향측심기를 이용한 생물량 추정 방법은 빠르고 정확하 게 광역범위를 조사 할 수 있다는 장점을 가지고 있지만 수 중 음향의 특성을 이해하는 것이 필요하다. 수중에서 음향에 영향을 주는 요인으로 어류나 플랑크톤 같은 수중생물은 물 론 부유물질, 기포, 수온, 염분 등이 있다(라 등 2005). 따라서 송, 수신 되는 음향(threshold level) 설정이 중요한데, 본 연 구에서는 $-130 \mathrm{~dB}$ 로 설정하여 수중 식생이 구분될 수 있도록 하였다. 하지만 음향 자료를 얻는 동안 조사선의 속도를 낮 게 유지하지 않으면 음향 자료로부터 식생의 종류를 구별하 기 어려운 단점이 있다(Sabol et al. 2002). 그러나 주어진 조 사선의 속도로 계획한 현장의 모든 정점을 3 시간 내외에 조 사가 가능했고, 조사 해역은 잘피 단일종으로 이루어졌기 때 문에 본 연구에서는 위와 같은 문제점의 영향을 받지 않았 다. 또한 식생의 밀도가 클수록 음향측심 측정값의 오차가 커지며 식물의 종류, 크기, 밀도에 의해 실제 바닥의 깊이가
과소평가 될 수 있다(Sabol et al. 2002).

연안의 수중식생 분석을 위한 음향측심기 이용은 이와 같 은 몇 가지 단점에도 불구하고 다이빙에 의한 직접 조사 방 법보다 노동과 비용에 있어서 효율적인 것으로 판단된다. 항 공 또는 인공위성 사진을 판독하여 식생을 분석하는 방법 역 시 광역 조사가 가능하지만 지역 수준에서 보면 해수의 상태 에 따라 크게 달라질 수 있고 수중 식생의 표면 정보만 제한 적으로 얻을 수 있다. 이에 반해 음향측심기는 상당히 깊은 수심에 존재하는 수중 식생도 지역 규모에서 양질의 생태자 료를 얻을 수 있다. 잘피 군락이 건강하지 못하고 규모도 점 점 감소하고 있는 우리 나라 연안에서 연안 생물의 파괴적인 표본 추출로 인한 생태계 손상과 피해도 상당할 것으로 추정 되기 때문에 본 연구와 같은 비파괴적 생태 조사방법이 권장 되어야 할 것이다.

\section{사 사}

본 연구는 2005년도 전남대학교 연구년교수연구비 지원에 의하여 연구되었습니다.

\section{참고문헌}

강돈혁, 조성호, 라형술, 김종만, 나정열, 명정구. 2006. 수중음향을 이용한 해초 서식처(Seagrass Habitat)의 공간 및 수직 분포 추 정. Ocean and Polar Res. 28: 225-236.

라형술, 윤관섭, 나정열. 2005. 거머리말(잘피) 서식지의 고주파 후방 산란 특성. 한국음향학회지 24: 97-102.

부경대학교. 2000. 하동화력 가동 및 건설공사로 인한 해양 영향 조 사 보고서. 부경대학교 해양과학공동연구소. $1120 \mathrm{pp}$.

이상용, 이성미, 지해근, 최청일. 2001. 남해안에서 자생하는 거머리 말(Zostera marina L.)식물의 분포와 생육지 환경. Korean J. Environ. Biol. 19: 313-320.

정승진, 유옥환, 서해립. 2004. 광양만 잘피밭에 서식하는 단각류의 계절변동과 식성. J. Kor. Fish. Soc. 37: 122-128.

Carbo R. and Molero A.C. 1997. Scattering strength of a Gelidium biomass bottom. Applied Acoustics 51: 343-351.

Dennis W.M. 1984. Aquatic macrophyton sampling: An Overview. In: Dennis W.M. and Isom B.G. (eds), Ecological assessment of macrophyton: Collection, use, and meaning of data. ASTM Special Technical Publication 843, Philadelphia, Pennsylvania. pp. 2-6.

Dennison W.C., Orth R.J., Moore K.A., Stevenson J.C., Carter V., Kollar S., Bergstron P.W. and Batiuk R.A. 1993. Assessing water quality with submersed aquatic vegetation. Bioscience 43: 86-94.

Duarte C.M. 1991. Seagrass depth limits. Aquat. Bot. 40: 363-377.

Duarte C.M. 1995. Submerged aquatic vegetation in relation to different nutrient regimes. Ophelia 41: 87-112.

Duarte C.M. and Cebrián J. 1996. The fate of marine autotrophic production. Limnol. Oceanogr. 41: 1758-1766.

Erhan M. 2005. A comparison of the contribution of zooplankton and nekton taxa to the near-surface acoustic structure of three 
Turkish seas. Mar. Ecol. 26: 17-32.

Fortes M.D. 1986. Taxonomy and Ecology of Philippine Seagrass. Ph. D. Dissertation, University of Philippines. Diliman, Quezon City, Philippines, $254 \mathrm{pp}$.

Guan W., Chamberlain R.H., Sabol, B.M. and Doering P.H. 1999. Mapping submerged aquatic vegetation with GIS in the Caloosahatchee Estuary: Evaluation of different interpolation methods. Marine Geodesy 22: 69-91.

Haga H., Ohtsuka T., Matsuda M. and Ashiya M. 2007. Echosounding observations of coverage, height, PVI, and biomass of submerged macrophytes in the southern basin of Lake Biwa, Japan. Jpn. Soc. Limnol. 8: 95-102.

Kaldy J.E. and Lee K-.S. 2007. Factors controlling Zostera marina L. growth in the eastern and western Pacific Ocean: Comparisons between Korea and Oregon, USA. Aquat. Bot. 87: 116-126.

Källström B., Nyqvist A., Åberg P., Bodin M. and André C. 2008. Seed rafting as a dispersal strategy for eelgrass (Zostera marina). Aquat. Bot. 88: 148-153.

Kevin M.B., Matthew P.W. and Charles A.W. 2007. Hydroacoustics as a tool for assessing fish biomass and size distribution associated with discrete shallow water estuarine habitats in Louisiana. Estuaries and Coasts 30: 607-617.

Kim K.Y. and Choi T.S. 2004. Variability in abundance and morphological attributes of Zostera marina L. from the southern coast of Korea. Bot. Mar. 47: 287-294

Komatsu T., Igarashi C. Tatsukawa K., Sultana S. Matsuoka Y. and Harada S. 2003. Use of multi-beam to map seagrass beds in Otsuchi Bay on the Sanriku coast of Japan. Aquat. Living Resour. 16: 223-230.

Lee S.Y., Choi C.I., Suh Y. and Mukai H. 2005. Seasonal variation in morphology, growth and reproduction of Zostera caespitosa on the southern coast of Korea. Aquat. Bot. 83: 250-262.

Madsen J.D. 1993. Biomass techniques for monitoring and assessing control of aquatic vegetation. Lake Reservoir Manage. 7: 141-154.

Mohamed A.A. 2007. Modeling coupling between eelgrass Zoster marina and water flow. Mar. Ecol. Prog. Ser. 338: 81-96.

Mumford T.F. Jr., Wyllie-Echeverria S. and Norris J. 1995. Inventory of eelgrass (Zostera spp.) in Washington State. In: Puget Sound Water Quality Authority, Puget Sound Research '95 Proceedings. Olympia, WA. pp. 508-515.

Norris J.G., Wyllie-Echeverria S., Mumford T., Bailey A. and Turner T. 1997. Estimating basal area coverage of subtidal seagrass beds using underwater videography. Aquat. Bot. 58: 269-287.

Pergent-Martini C., Pasqualini V., Ferrat L. and Pergent G. 2006. Ecological data in integrated coastal zone management: Case study of Posidonia oceanica meadows along the corsican coastline (Mediterranean Sea). Environ. Manage. 38: 889-895.

Sabol B.M., Melton Jr. R.E., Chamberlain, R., Doering P.H. and Haunert K. 2002. Evaluation of a digital echosounder system for detection of submersed aquatic vegetation. Estuaries 25: 133-141.

Short F.T. and Neckles A.H. 1999. The effect of global climate change on seagrasses. Aquat. Bot. 63: 169-196.

Short F., Carruthers T. Dennison W. and Waycott M. 2007. Global seagrass distribution and diversity: A bioregional model. J. Exp. Mar. Bio. Ecol. 350: 3-20.

Stent C.J. and Hanley S. 1985. A recording echosounder for assessing submerged aquatic plant populations in shallow lakes. Aquat. Bot. 21: 377-394.

Winfield I.J., Onoufriou C., O'Connel M.J., Godlewska M., Ward R.M., Brown A.F. and Yallop M.L. 2007. Assessment in two shallow lakes of a hydroacoustic system for surveying aquatic macrophytes. Hydrobiologia 584: 111-119.

Received 5 January 2008

Accepted 20 February 2008 